\title{
Corporate social responsibility and innovative capacity: intersection in a macro-level perspective
}

Article

Accepted Version

Creative Commons: Attribution-Noncommercial-No Derivative Works 4.0

Halkos, G. and Skouloudis, A. (2018) Corporate social responsibility and innovative capacity: intersection in a macrolevel perspective. Journal of Cleaner Production, 182. pp. 291300. ISSN 0959-6526 doi:

https://doi.org/10.1016/j.jclepro.2018.02.022 Available at https://centaur.reading.ac.uk/75508/

It is advisable to refer to the publisher's version if you intend to cite from the work. See Guidance on citing.

To link to this article DOI: http://dx.doi.org/10.1016/j.jclepro.2018.02.022

Publisher: Elsevier

All outputs in CentAUR are protected by Intellectual Property Rights law, including copyright law. Copyright and IPR is retained by the creators or other copyright holders. Terms and conditions for use of this material are defined in the End User Agreement.

www.reading.ac.uk/centaur 
Central Archive at the University of Reading

Reading's research outputs online 


\title{
Corporate social responsibility and innovative capacity: Intersection in a macro-level perspective
}

\author{
George Halkos ${ }^{1}$ \& Antonis Skouloudis ${ }^{2,3 *}$ \\ ${ }^{1}$ Laboratory of Operations Research, Department of Economics, \\ University of Thessaly, Volos, 38 333, Greece \\ ${ }^{2}$ Centre for Environmental Policy and Strategic Environmental Management, Department of \\ Environment, University of the Aegean, Mytilene, 81 100, Greece \\ ${ }^{3}$ Marketing and Reputation, Henley Business School, University of Reading, Greenlands, \\ Henley-on-Thames, RG9 3AU, United Kingdom \\ *corresponding author
}

\begin{abstract}
This study explores the link between macro (country-level) corporate social responsibility penetration and innovative capacity presenting new findings on the potential influence that various elements shaping innovation have on the endorsement of social responsibility among national business systems. Relying on cross-sectional data, a composite index for quantifying the proliferation of corporate social responsibility is employed and well-established innovation metrics are utilized. Findings do not contradict the preceding but limited evidence on corporate social responsibility practices considering innovation, nevertheless, the negative relationships found in our empirically supported and internally consistent proposed models merit supplementary consideration and examination. The paper offers new insights to innovation theorists and political economy researchers for more detailed investigations of critical drivers, such as innovation, which shape country-level corporate social responsibility specificities of and potentially encapsulate a critical parameter in the self-regulation agendasetting of business entities. In these lines the study indicates that innovation, as moderator of corporate social responsibility adoption, has to be included in empirical models where measures of corporate social responsibility penetration and innovative potential are employed.
\end{abstract}

Keywords: Corporate social responsibility; national innovative capacity; country index; macro-level analysis. 


\section{Introduction}

Over the past three decades the notion of corporate social responsibility (CSR) has reached a level of maturity redefining business models and supporting shared-value creation (Porter and Kramer 2011). Recent drastic socioeconomic and political changes, inefficiencies in the public sector of many countries along with limited resources due to macroeconomic instability (e.g. the 2008-09 economic downturn), urge business to engage more actively in the mitigation of pressing social and environmental problems beyond a mere management of externalities and towards a value creation for the common good. In this context, a growing number of companies are shaping CSR strategies to stimulate innovation and differentiate themselves from peers (Hull and Rothenberg, 2008). Numerous scholars, given the capital scarcity of the recent economic turbulence, have emphasized on business model innovation as a facilitator of organizational, technological and strategic change. Such change can be materialized through the leverage of (tangible and intangible) resources around the business case for CSR and in order to amplify cost and differentiation advantages over competitors (Mitchell and Coles, 2003; Johnson and Suskewicz, 2009; Amit and Zott, 2010; Yunus et al., 2010).

Posing a more systemic view of organizational performance (strategic-operational levels) and mission (culture and value system levels), the multifaceted CSR construct offers an array of opportunities to innovate through new products-services, emerging markets, organizational processes or management systems and structures (Maroušek, 2013; Maroušek et al., 2015; 2016). Engaging in meaningful (i.e. strategic) CSR eventually leads to innovation as both concepts are built around reflection, learning and performance refinement (Grieshuber, 2013); a 'thinking-out-of-the-box' mentality. Under this 'lens', business are no more viewed as mere generators of wealth but as creators of long-term stakeholder value (Freeman et al. 
2010), as citizens (Moon et al., 2005) as well as primary movers in social capital accumulation and social change (Donaldson and Dunfee, 1999; Kaasa et al., 2007). In this respect, several scholars (e.g. see Pujari, 2006; Cohen and Winn, 2007; Schaltegger and Wagner, 2011) have pinpointed the mediating role of CSR considerations in the organizational capability to innovate as it potentially offers an expanded viewpoint of business performance among diverse aspects and dimensions (i.e. a triple-bottom-line perspective) and different knowledge sources (e.g. external stakeholder groups previously undetected).

Motivated by the limited empirical attention to innovation as a driver of sustainable business behavior, this paper takes on a macro-level perspective and attempts to shed light on the identified, yet understudied, potential relationships between the two constructs. To the best of our knowledge, our study is the first to investigate links between innovation elements and CSR at the country-level. A recent wave of studies (Gallego-Alvarez et al. 2011; Bocquet and Mothe, 2011; Luo and Du, 2015; Shen et al., 2016; Ratajczak and Szutowski, 2016) has indeed attempted to clarify intersections between the two concepts, with meaningful managerial and research implications, yet, they retain a firm-level focus. Motivated by such studies and given that relevant literature is still thin on the ground, primarily pertaining to normative arguments and micro-level empirical studies, we seek to make a contribution to the macro-level CSR research by exploring the influence of salient innovation attributes on country-level CSR penetration. Our aim is to provide a better understanding of how CSR penetration relates with core elements of national innovative capacity and offer fertile ground for theory-building and further comparative research on the innovative and value-driven potential of CSR activities. 
To this end, the rest of the paper is divided in four sections. section 2 outlines prior literature. Section 3 describes the research methods, the variables employed and the models based on the selected variables to explore the relationship between CSR and innovation. In section 4 , the results of the empirical analysis are presented. These are then discussed in section 5 which also reflects on the main findings, implications and opportunities for future research.

\section{Literature review}

Innovation: the concept

Innovation encapsulates the development and implementation of new combinations of resources (i.e. production factors) which yield added value for the entity that adopts it and increase the welfare of its stakeholders (Drucker, 1985; Baldwin and Curley, 2007). It can be found in various forms (product, market, process or social innovation), derived from diverse sources (closed vis-a-vis open innovation) and pertain to different scopes of change (disruptive, incremental or reapplied innovation) (Baldwin and Curley, 2007; Chesbrough, 2003; MacGregor and Fontrodona 2008). Already in 1984, Drucker stressed the fruitful possibilities of turning social problems into new business opportunities, economic benefits, productive capacities, human competencies and ultimately wealth. In this regard, the bottomof-the-pyramid (BOP) literature is a key manifestation in the CSR-innovation relationship, highlighting the potential connections between lucrative business opportunities and the mitigation of problems found among socially-disadvantaged groups (i.e. pertaining to the 'bottom-of-the-pyramid' - eg. see Prahalad, 2005; Prahalad and Hart, 2002; Prahalad and Hammond, 2002; Fox, 2004; Bendell and Visser, 2005). In a similar vein, eco-efficiency ideas and technologies fulfilling win-win conditions in terms of business revenue and the 
alleviation of pressing environmental problems pertain to an important strand of the business literature that focuses on ecologically-oriented innovation and sustainable change (Hockerts 2003; Hockerts and Wüstenhagen 2010; Halme and Laurila, 2008). In this context, environmentally-responsible firms are driven by process and/or product innovations in an attempt to reduce the ecological footprint in terms of energy efficiency, benign waste management and 'greener' products.

Nevertheless, to successfully engage in such actions the external conditions reflect an essential ingredients in offering the right circumstances which will support the "creative destruction' of existing structures, know-how or routines (Schumpeter, 1994) and transform new ideas into more responsible behavioural patterns (in nonfinancial terms) and win-win solutions for business and society at large. In this respect, the association of CSR with innovation is limited in the available literature, mostly fueled by conceptual arguments and normative assumptions (McWilliams and Siegel, 2000) supported by scarce empirical evidence explaining the relationship between the two concepts (Locket et al., 2006). This is despite the dynamic and critical role of innovation in solving environmental and social issues, promoting sustainable macroeconomic growth as well as competitiveness. As Googins (2013) indicates: “(...) ironically, neither the cultural attribute nor the competencies around innovation have been transferred over to CSR either in its conception or its practice. This dissonance may somewhat explain why CSR has remained for so long on the periphery of business and has had such difficulty in being seen as integral to the business and a strategic component" (p.90). With business being a key player in spurring sustainability transitions over key socioeconomic and environmental challenges facing society, linking CSR with innovation streams opens up unique opportunities to the technical realization and rigorous development of solutions that increase both brand value and social prosperity. 


\section{Innovation-focused CSR}

Firms considered pace-setters in CSR are nowadays reaping business opportunities linked with the alleviation of barriers to sustainable growth (poverty, demographic change, climate change, resource scarcity). Possessing a hard-to-imitate range of tangible and intangible assets such firms operate as a repository of knowledge, techniques as well as human capital and catalyse socially or environmentally responsible (i.e. sustainable) and scalable solutions to pressing challenges undermining development at the various scales (local, regional, global). Innovation-focused CSR drives organizational change, looks beyond the mere management of externalities and drives a more holistic strategic management approach towards sustainability challenges (Roome, 2011). Companies that develop and introduce new ideas to their everyday operations and the market are in a better position to thrive in a turbulent and rapidly changing environment. Endorsing innovation has been demonstrated to have a positive influence on both organizational performance and environmental sustainability (Chandler et al., 2000; Zahra and Covin, 1995, Zahra and Neubaum, 1998). Common examples of innovative CSR is the investment in 'greener' products and services as well as resource-efficient techniques reducing environmental impact along with the promotion of circular economy and eco-management principles, promotion of organizationwide employee involvement and diversity or novel business models beyond the linear 'production-sales-after sales' business thinking (Yang and Konrad, 2011; Grieshuber, 2013; Crets and Celer, 2013). Similarly, Rake and Grayson (2009) highlight the capability of CSR to act as a catalyst that can be employed to deal with urgent social problems which if managed properly can be transformed into wide scale social opportunities. Grayson and Hodges (2004) indicate that the competitive instinct and entrepreneurialism characterizing business entities induces them to explore for innovative solutions in non-traditional areas such as those pertaining to the CSR domain. These authors describe such corporate social 
opportunities as commercially viable innovative activities which also advance environmental and social sustainability. In a similar vein Porter and van der Linde (1995) assert that environmental considerations do not pose a trade-off between the private costs and social benefits; instead, they encapsulate a high innovative potential that may yield competitive advantages for the organization. This 'Porter hypothesis' is extended in Porter and Kramer (2006; 2011) who support the need for a better link between CSR practices with business strategy as such a connection will facilitate innovative solutions for society at large while shaping robust competitive advantages for the individual for-profit entity. Through new products-services, entering unserved markets or devising innovative business models, such 'enlightened' companies can upgrade their growth and competitiveness potential by better addressing their effects to society and the environment, i.e. by redefining their CSR vision and strategy. Such placement of CSR at the core of business strategy (i.e. less of a 'bolt-on' and more of a 'built-on') can be successfully endorsed by the propensity to innovate. Under this scope, Teece $(2007 ; 2010)$ draws on the dynamic capabilities theory to conceptualize the ability of upper management to articulate innovative responses to a turbulent socioeconomic and physical environment by addressing critical CSR-related conditions and underlying responsibility dilemmas.

\section{Innovation vis-a-vis CSR: some empirical findings}

Research findings indicate that CSR can have a positive impact on stakeholder value and certain management strategies, one of which being innovation (Husted and Allen, 2007; Trebucq and Evraert, 2008). In this respect, a correlation has been identified between research and development (R\&D) - a critical element for innovation - and CSR, as companies apply CSR principles to their production systems that require modifications in the 
technology applied and involve R\&D expenditures (Siegel, 2001; Bansal, 2005). Trebucq and Evraert (2008) relatively indicate an association between the development of CSR accounting and reporting systems with the R\&D of European firms. Brammer and Millington (2008) denote an association between $R \& D$ intensity with charitable contributions (as a surrogate of CSR engagement) while Lopez et al. (2008) also confirm a positive relationship between R\&D expenditures and CSR-oriented practices and targets, yet, their findings do not support a bicausal relation between the two variables. MacGregor and Fontrodona (2008) examine the CSR-innovation links in European firms and assert that CSR-driven innovation is aimed at products-services that retain a social purpose, while, in contrast, innovation-driven CSR is found to be value-driven and aligned with creating social processes. The value creation via innovative CSR projects is also supported by Husted and Allen (2007) with their arguments to be in line with the positive externalities associated with innovative activities, such as the social returns pertaining to a material CSR agenda.

\section{Material and methods}

Model specifications

In our research, the proposed linear model specification is as follows:

$$
y=X \beta+\varepsilon
$$

Where $\mathrm{y}$ is a vector $(\mathrm{nx} 1)$ for the dependent variable (in our case the constructed index, NCSRI), $\mathrm{X}$ is a matrix (nxk) of the explanatory variables; $\beta$ and $\varepsilon$ are vectors of $(\mathrm{kx} 1)$ and (nx1) respectively. 
Country-level CSR penetration is proxied by the composite index (NCSRI) obtained from Skouloudis et al. (2014) and Halkos and Skouloudis (2016; 2017) who extend Gjølberg's (2009) assessment methodology and utilize country data from 16 international CSR initiatives, environmental and social standards, 'best-in-class' rankings and ethical investment stock exchange indices ${ }^{1}$. NCSRI was selected as it signifies the first CSR-specific index to rank a considerable sample of countries around the world $(n=86)$ according to CSR penetration and endorsement in line with related global standards and initiatives. Each one of the 16 NCSRI 'components' for country-level CSR appraisal indicates the number of organizations endorsing the specific CSR 'variable'. Skouloudis et al. (2014) select the year 2012 as the reference period for data capture and a 'cut-off' value of inclusion in at least four out of the sixteen CSR 'sub-indices' (i.e. national business sectors with presence in less than four components of the NCSRI were removed from the assessment). In this respect, 86 out of the 196 countries worldwide, spanning from all geographical regions of the world are ranked in terms of CSR penetration and offering an encompassing worldview of CSR penetration. The NCSRI reveals deficient CSR penetration as well as considerable variation between countries, with the majority of the assessed nations to be lagging in CSR endorsement through international schemes and initiatives (see Skouloudis et al., 2014). The overall NCSRI ranking indicates that in only 19 countries there is a considerable proportion of companies active in CSR engagement. In total, 12 countries were assigned positive scores; these are mostly European countries and it only two pertaining to the Eastern Asia and

\footnotetext{
${ }^{1}$ These sixteen CSR 'variables' pertain to:

(a) certification to management system standards (ISO 14001, OHSAS 18001, SA 8000),

(b) adoption of nonfinancial accounting and reporting guidelines and inclusion in relevant databases/surveys (Global Reporting Initiative, Carbon Disclosure Project, Greenhouse Gas Protocol, KPMG triennial survey on CSR reporting),

(c) subscription to sets of overarching principles and business-led coalitions (Global Compact, World Business Council for Sustainable Development),

(d) inclusion in CSR/sustainability stock exchange indices (Ethibel Sustainability Index, FTSE4Good Global Index, Dow Jones Sustainability World Enlarged Index, ECPI Global ESG Alpha Equity Index, MSCI World ESG Index, and

(e) international CSR rankings (World's Most Ethical companies, Global 100 Most Sustainable Corporations).
} 
Pacific region (Australia and Singapore). Switzerland is ranked first, along with three Nordics (Sweden, Finland and Denmark). Canada and Japan are assigned a close to zero score, the USA and Germany received negative scores while Saudi Arabia has the lowest score (-37.06) in this country ranking. The full list of the NCSRI scores for the 86 countries that comprise the study's sample is presented in Appendix 1.

\section{Independent variables}

A number of independent variables are considered. Particularly, the innovative potential of nations is approximated through three different composite measures set forth by (i) the World Economic Forum (WEF, 2013), (ii) the European Institute of Business AdministrationINSEAD (Dutta, 2012), and (iii) the European Business School (Lopez-Claros and Mata, 2011). This resulted in the following three different model specifications in our assessment.

First, the World Economic Forum (WEF) measurement of macro-level innovation potential (part of the annual Global Competitiveness Report) is assessed through a composite measure examining the following parameters:

Capacity for innovation (CAP) describing how companies in a country obtain technology; i.e. by exclusively from licensing or imitating foreign companies vs. by conducting formal research and pioneering their own new products and processes.

Quality of scientific research institutions (RES_INST), indicating the quality of scientific research institutions in a country.

Company spending on research and development (RD_SP), which examines the extent to which companies invest on $R \& D$.

University-industry collaboration in $R \& D$ (UNI_IND) examining the extent to which business and higher education institutions collaborate on R\&D in a country. 
Government procurement of advanced technology products $(G O V)$, that reveals whether government procurement decisions foster technological innovation in a country.

Availability of scientists and engineers (SCI_ENG), indicating the availability of scientists and engineers in a country.

Finally, patent applications (PCT), which denotes the number of applications filed under the Patent Cooperation Treaty (PCT) per million population.

Second, INSEAD's Global Innovation Index (GII) relies on two sub-indices describing enabling conditions that facilitate country-level innovation and the outcomes of innovative activities within the country's economy while it is built around a number of pillars.

Institutions (INST), describing the national institutional framework in terms of the attraction of business opportunities and by fostering growth through good governance and adequate levels of protection and incentives for innovation.

Human capital and research (HUM_CAP), illustrating the level and standard of education and research activity in a country.

Infrastructure (INFR), referring to information and communication technologies, energy supply and the dissemination-quality of general infrastructure.

Market sophistication (MARK), underpinning the critical importance of credit, investment funds and access to international markets for innovations to be developed.

Business sophistication (BUSS), pertaining to how conducive are domestic business entities to innovation activities through the employment of highly qualified professionals-technicians. 
Knowledge and technology outputs (TECH), covering the outputs of inventions and/or innovations in terms of patent applications, utility model applications as well as scientific and technical articles published in peer-reviewed journals.

Creative outputs (CRE), including creative intangibles, proxies to get at creativity and creative outputs in an economy (data on consumption, trade, and production of entertainment and cultural products) as well as the creation of content online as a critical estimate of the overall national creative output.

Third, the Innovation Capacity Index (ICI), proposed by the European Business School, identifies the innovative potential of nations through the following explanatory variables.

Institutional environment (INST_env), which refers to good governance and effective country policy assessment.

Human capital training and social inclusion (HUM), which pertains to aspects of the country's education system as well as social inclusion and equity policies.

Regulatory and legal framework (LEG), that includes issues describing the ease and effective legal procedures of doing business in the domestic economy.

Research and development $(R \& D)$, assessing available research and development infrastructure and workforce along with registered patents, trademark applications and royalty-license fees.

Adoption and use of information and communication technologies (COMM); pertaining to the penetration and quality of efficient telecommunication- and IT-related infrastructures. 


\section{Control variables}

To isolate country-level effects on CSR penetration, a number of variables were employed in order to control for differences in socioeconomic conditions among countries. These controls pertain to the Human Development Index (HDI) for human development per country, the GINI coefficient for income distribution, GDP per capita (GDP_cap) proxying the country's wealth, macroeconomic and political stability (MACRO_stab; POL_stab) derived from the World Bank's Worldwide Governance Indicators project as well as foreign direct investments net inflows (FDI) as percentage of GDP.

In these lines, the proposed model specification 1, utilizing WEF's elaboration of national innovative potential, is as follows:

NCSRI $=f$ (CAP, RES_INST, RD_SP, UNI_IND, GOV, SCI_ENG, PCT, HDI, GINI, GDP_cap, MACRO_stab, POL_stab, FDI)

The proposed specification for model 2, employing GII's innovation construct is:

NCSRI $=f($ INST, HUM_CAP, INFR, MARK, BUSS, TECH, CRE, GINI, GDP_cap, MACRO_stab)

Finally, the specification for model 3, relying on ICI's conception of country-level innovation, is as follows:

$$
\text { NCSRI }=f(\text { INST_env, HUM, LEG, R\&D, COMM, GINI, GDP_cap, FDI })
$$




\section{Findings}

Table 1 presents the descriptive statistics of the data used in our research. Specifically part (a) presents the descriptive statistics for the 4 indexes as well as the control variables while (b)(d) present the descriptive statistics of the components of WEF, GII and ICI respectively. It is evident that there are no large differences between mean and median values for the variables considered having almost in all cases symmetric distributions. With a few exceptions the Jarque-Bera test for normality and its associated P-values do no reject the null hypothesis that data have a normal distribution. Although the sample considered consists of 86 countries the descriptive statistics refer to countries with no missing observations. Similarly Table 2 presents the Pearson correlation coefficient between the 4 indexes and the control variables. 
Table 1: Descriptive statistics of the variables considered

\begin{tabular}{|c|c|c|c|c|c|c|c|c|c|}
\hline \multicolumn{10}{|c|}{ a) Indexes and control variables } \\
\hline NCSRI & WEF & GII & ICI & GDP_cap & HDI & GINI & POL_stab & MACRO_stab & FDI \\
\hline Mean -16.74560 & 3.817333 & 42.75200 & 56.98933 & 23174.51 & 0.792573 & 37.76533 & 0.085333 & 4.880533 & 7.464272 \\
\hline Median -21.72803 & 3.500000 & 40.70000 & 55.00000 & 13142.05 & 0.813000 & 36.80000 & 0.200000 & 4.910000 & 2.507793 \\
\hline Maximum 20.64357 & 5.800000 & 68.20000 & 80.30000 & 105447.1 & 0.942000 & 63.10000 & 1.400000 & 6.800000 & 255.4233 \\
\hline Minimum -35.43696 & 2.400000 & 23.10000 & 36.80000 & 858.9334 & 0.505000 & 23.00000 & -2.500000 & 2.820000 & 0.001679 \\
\hline Std. Dev. 14.71895 & 0.949448 & 12.06127 & 11.30357 & 23558.72 & 0.108926 & 9.570245 & 0.954604 & 0.891749 & 29.51224 \\
\hline Skewness 0.890259 & 0.674085 & 0.235408 & 0.306705 & 1.478924 & -0.740730 & 0.402865 & -0.499510 & -0.249102 & 8.075253 \\
\hline Kurtosis 2.806150 & 2.123845 & 1.837203 & 1.981184 & 5.002138 & 2.790964 & 2.294609 & 2.339319 & 2.511266 & 68.26016 \\
\hline J-B 10.02443 & 8.078789 & 4.918019 & 4.419555 & 39.86695 & 6.995061 & 3.583677 & 4.482938 & 1.522089 & 14124.15 \\
\hline Probability 0.006656 & 0.017608 & 0.085520 & 0.109725 & 0.000000 & 0.030272 & 0.166653 & 0.106302 & 0.467178 & 0.000000 \\
\hline Observ $\quad 75$ & 75 & 75 & 75 & 75 & 75 & 75 & 75 & 75 & 75 \\
\hline \multicolumn{10}{|l|}{ (b) WEF components } \\
\hline & GOV & CAP & PCT & RES & _INS & RD_SP & SCI_ENG & UNI_IND & \\
\hline Mean & $3,622.667$ & $3,713.333$ & $5,119.87$ & 4,29 & 3.333 & $3,618.67$ & $4,337.333$ & $4,114.667$ & \\
\hline Median & $3,600.000$ & $3,400.000$ & $5,800.00$ & 4,10 & 0.000 & $3,300.00$ & $4,300.000$ & $4,100.000$ & \\
\hline Maximum & $5,300.000$ & $5,900.000$ & $3,110.00$ & 6,30 & 0.000 & $5,900.00$ & $6,200.000$ & $5,900.000$ & \\
\hline Minimum & $2,000.000$ & $2,300.000$ & 0.00000 & 2,50 & 0.000 & $2,300.00$ & $3,300.000$ & $2,500.000$ & \\
\hline Std. Dev. & 0.597421 & 0.918479 & $8,036.18$ & 1,01 & 0.263 & 0.934720 & 0.654459 & 0.868004 & \\
\hline Skewness & 0.158241 & 0.766561 & $1,648.19$ & 0.20 & 8910 & 0.856867 & 0.321297 & 0.238514 & \\
\hline Kurtosis & $3,159.595$ & $2,586.303$ & $4,751.44$ & 1,95 & 2.427 & $2,669.95$ & $2,477.381$ & $2,023.701$ & \\
\hline Jarque-Bera & 0.392599 & $7,880.028$ & $4,354.28$ & 3,97 & 4.946 & $9,518.19$ & $2,143.928$ & $3,689.738$ & \\
\hline Probability & 0.821766 & 0.019448 & .000000 & 0.13 & 37041 & 0.008573 & 0.342335 & 0.158046 & \\
\hline Observations & 75 & 75 & 75 & & 75 & 75 & 75 & 75 & \\
\hline \multicolumn{10}{|l|}{ (c) GII components } \\
\hline & CRE & HUM_CAP & INFR & MAR & & BUSS & INST_env & ТЕCH & \\
\hline Mean & 37.96753 & 41.57922 & 42.99870 & 46.348 & 305 & 45.10909 & 64.07792 & 36.55065 & \\
\hline Median & 36.00000 & 42.00000 & 43.20000 & 44.20 & 000 & 42.30000 & 67.20000 & 34.00000 & \\
\hline Maximum & 65.00000 & 68.30000 & 69.80000 & 85.50 & 000 & 76.90000 & 95.30000 & 72.00000 & \\
\hline Minimum & 15.70000 & 10.00000 & 16.80000 & 16.90 & 000 & 27.50000 & 16.20000 & 6.400000 & \\
\hline Std. Dev. & 10.57595 & 14.01914 & 12.54492 & 14.55 & 115 & 10.54283 & 20.07558 & 14.65865 & \\
\hline Skewness & 0.279144 & 0.003119 & 0.090471 & 0.474 & & 0.637076 & -0.193089 & 0.433175 & \\
\hline Kurtosis & 2.363184 & 2.205955 & 2.051698 & 2.6580 & & 2.954073 & 2.037288 & 2.394647 & \\
\hline Jarque-Bera & 2.301082 & 2.023005 & 2.990218 & 3.262 & 341 & 5.215383 & 3.452000 & 3.583761 & \\
\hline Probability & 0.316465 & 0.363672 & 0.224224 & $0.195^{\circ}$ & & 0.073705 & 0.177995 & 0.166646 & \\
\hline Observations & 77 & 77 & 77 & 77 & & 77 & 77 & 77 & \\
\hline \multicolumn{10}{|l|}{ (d) ICI components } \\
\hline & HUM & INST_env & R\&D & COM & & LEG & & & \\
\hline Mean & 63.91711 & $56.9 \overline{6} 184$ & 29.48158 & 62.373 & & 69.76053 & & & \\
\hline Median & 64.05000 & 53.65000 & 20.70000 & 62.400 & 000 & 69.20000 & & & \\
\hline Maximum & 88.90000 & 85.60000 & 75.60000 & 92.600 & & 96.20000 & & & \\
\hline Minimum & 40.80000 & 34.10000 & 3.600000 & 30.200 & 000 & 45.20000 & & & \\
\hline Std. Dev. & 12.81453 & 14.71907 & 19.98990 & 16.634 & 408 & 10.07652 & & & \\
\hline Skewness & -0.025297 & 0.470624 & 0.749702 & 0.0225 & 515 & 0.128181 & & & \\
\hline Kurtosis & 1.932557 & 2.043317 & 2.327403 & 1.8575 & 592 & 3.020612 & & & \\
\hline Jarque-Bera & 3.616318 & 5.703771 & 8.551902 & 4.1392 & 225 & 0.209462 & & & \\
\hline Probability & 0.163956 & 0.057735 & 0.013899 & 0.1262 & & 0.900567 & & & \\
\hline Observations & 76 & 76 & 76 & 76 & & 76 & & & \\
\hline
\end{tabular}


Table 2: Correlation coefficients between indexes and control variables (Pearson correlation coefficients above and P-values below)

\begin{tabular}{|l|c|c|c|c|c|c|c|c|c|}
\hline & NCSRI & WEF & GII & ICI & GDP_cap & HDI & GINI & POL_stab & MACRO_stab \\
\hline \multirow{2}{*}{ WEF } & 0.768 & & & & & & & & \\
& 0.000 & & & & & & & & \\
\hline \multirow{2}{*}{ GII } & 0.793 & 0.880 & & & & & & & \\
& 0.000 & 0.000 & & & & & & & \\
\hline \multirow{2}{*}{ ICI } & 0.782 & 0.875 & 0.963 & & & & & & \\
& 0.000 & 0.000 & 0.000 & & & & & & \\
\hline \multirow{2}{*}{ GDP_cap } & 0.661 & 0.770 & 0.770 & 0.779 & & & & & \\
& 0.000 & 0.000 & 0.000 & 0.000 & & & & & \\
\hline \multirow{2}{*}{ HDI } & 0.654 & 0.693 & 0.850 & 0.869 & 0.729 & & & & \\
& 0.000 & 0.000 & 0.000 & 0.000 & 0.000 & & & & \\
GINI & -0.366 & -0.401 & -0.453 & -0.451 & -0.452 & -0.456 & & & \\
& 0.001 & 0.000 & 0.000 & 0.000 & 0.000 & 0.000 & & & \\
\multirow{2}{*}{ POL_stab } & 0.575 & 0.616 & 0.779 & 0.767 & 0.676 & 0.799 & -0.384 & & \\
\hline MACRO_st & 0.000 & 0.000 & 0.000 & 0.000 & 0.000 & 0.000 & 0.000 & & \\
ab & 0.115 & 0.240 & 0.304 & 0.306 & 0.381 & 0.277 & -0.036 & 0.293 & \\
\hline \multirow{2}{*}{ FDI } & 0.297 & 0.029 & 0.005 & 0.005 & 0.000 & 0.012 & 0.752 & 0.007 & \\
& 0.097 & 0.151 & 0.199 & 0.207 & 0.392 & 0.141 & -0.065 & 0.191 & \\
\hline
\end{tabular}

Figure 1 (a-c) presents the fitted line plots of NCSRI against the three innovation indexes. The bivariate relationships are all positive with a moderate to good predictability ranging from almost $59 \%$ to $63 \%$.

Table 3 presents the OLS regression model specifications and the estimates for the three proposed models. Specifically, the first column presents the WEF model formulation with the other two columns referring to GII and ICI specifications.

As it can be seen in Model 1, 'patent applications' (PCT) and 'quality of scientific research institutes' (RES_INST) are statistically significant at all levels of significance with the former having a low magnitude and the latter a very high affecting NCSRI positively. ‘Capacity for innovation' (CAP) affects negatively NCSRI with a high magnitude while 'political stability' (POL_stab) has a positive effect, yet, both variables are statistically insignificant. 
According to the Model 2 formulation, 'infrastructure' (INFR), 'market sophistication'(MARK) and 'GDP per capita' (GDP_cap) are significant at all significance levels $(0.01,0.05,0.1)$ and affect positively NCSRI. 'Human capital and research' (HUM_CAP) is statistically significant at the 0,05 level and 'knowledge and technology' is statistically significant at the 0,1 level with the latter affecting negatively NCSRI. All variables present a low magnitude apart from 'macroeconomic stability'. 'Creative outputs' (CRE) and 'business sophistication' (BUSS) are of low magnitude and found to be insignificant.

Finally, in the Model 3 specification all variables are significant at all statistical levels and present low magnitudes. 'Research and development' (R\&D) as well as 'GDP per capita' (GDPc) affect positively NCSRI, while 'human capital training' (HUM), foreign direct investments (FDI) and GINI have a negative effect. The model performs very well in all diagnostic tests applied with no indication of any problem of normality (Jarque-Bera), heteroskedasticity (Harvey, White), specification errors (Ramsey RESET) as well as ARCH effect.

The constant term is statistically significant at all levels of significance in all three model specifications. 
Figure 1: Fitted line plots of the NCSRI and the innovation indexes

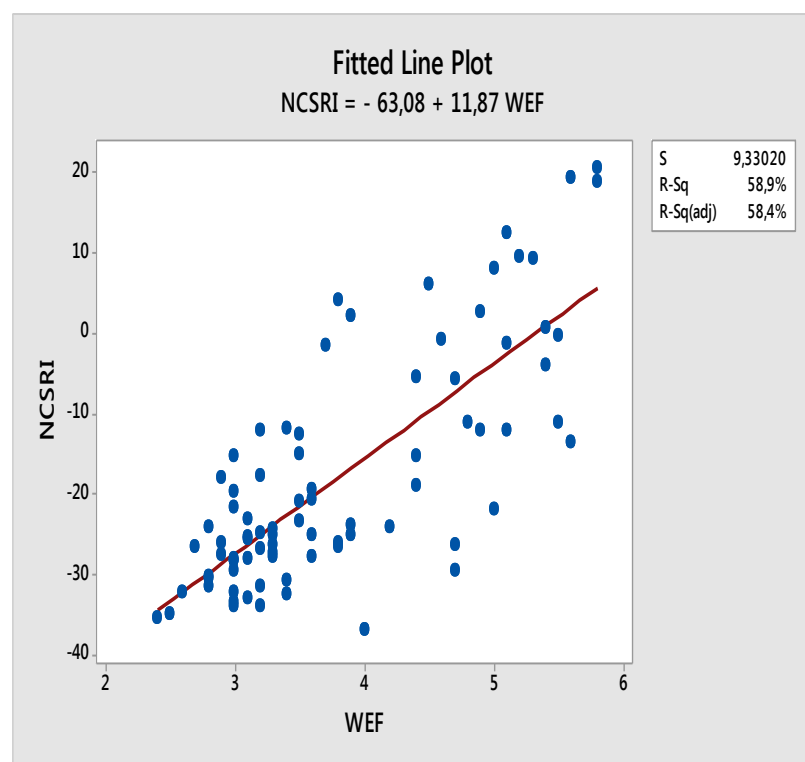

(a)

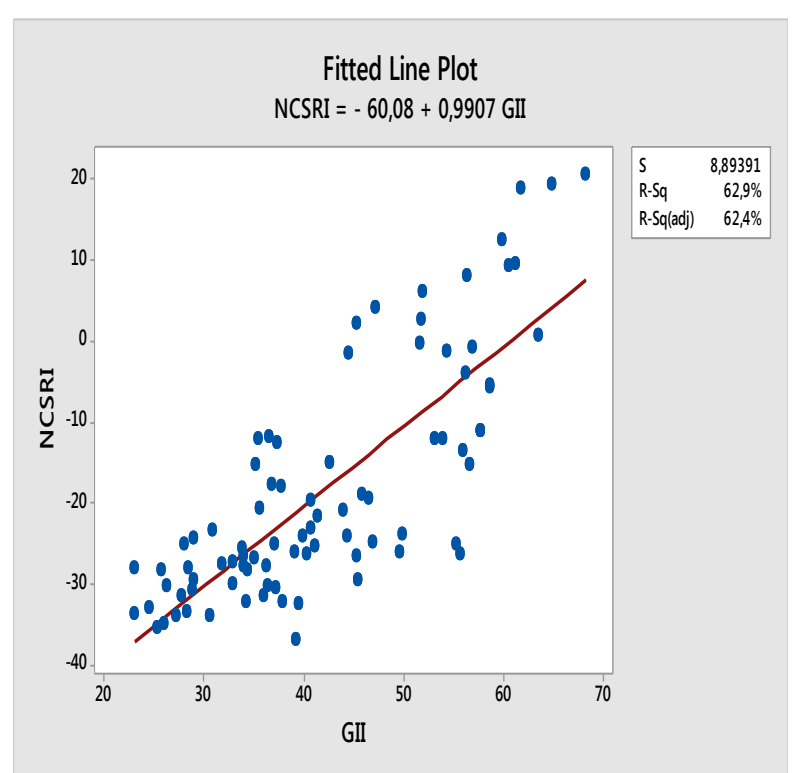

(b)

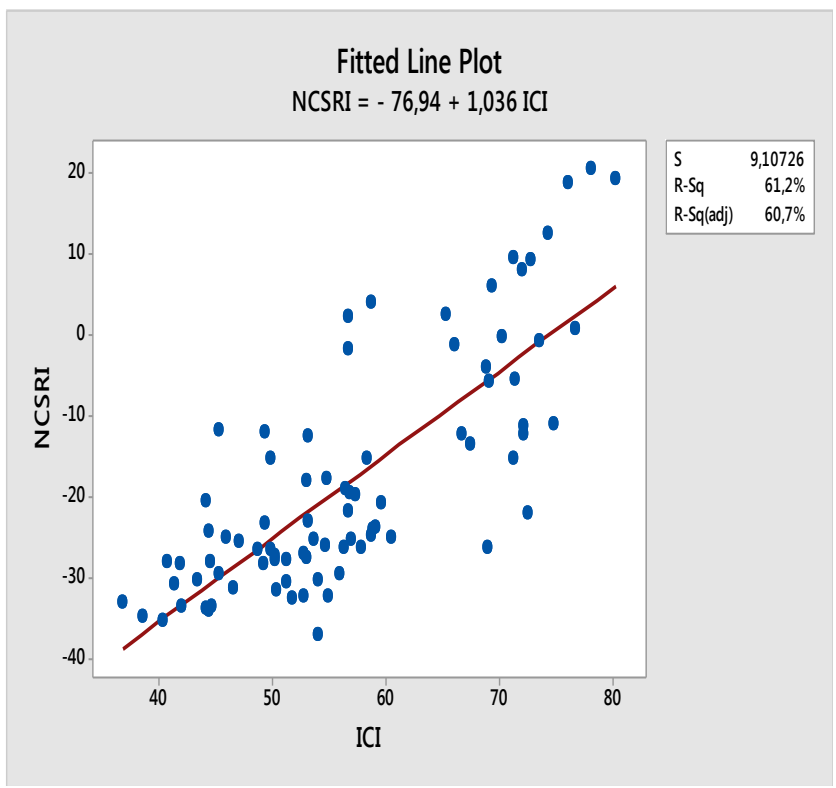

(c) 
Table 3: OLS model results and diagnostics tests (P-Values in brackets).

\begin{tabular}{|c|c|c|c|}
\hline Variables & $\begin{array}{l}\text { Model } 1 \\
\text { WEF }\end{array}$ & $\begin{array}{c}\text { Model } 2 \\
\text { GII }\end{array}$ & $\begin{array}{l}\text { Model } 3 \\
\text { ICI }\end{array}$ \\
\hline Constant & $\begin{array}{l}-32.0288 \\
{[0.0000]}\end{array}$ & $\begin{array}{l}-37.2067 \\
{[0.0000]}\end{array}$ & $\begin{array}{l}-42,3813 \\
{[0.0001]}\end{array}$ \\
\hline $\begin{array}{c}\text { CAP } \\
\text { (Capacity for innovation) }\end{array}$ & $\begin{array}{c}-4.399 \\
{[0.1276]}\end{array}$ & & \\
\hline $\begin{array}{c}\text { PCT } \\
\text { (Patent applications) }\end{array}$ & $\begin{array}{l}0.12836 \\
{[0.0000]}\end{array}$ & & \\
\hline $\begin{array}{c}\text { RES_INST } \\
\text { (Quality of scientific research institutions) }\end{array}$ & $\begin{array}{c}5.6295 \\
{[0.0090]}\end{array}$ & & \\
\hline $\begin{array}{c}\text { POL_stab } \\
\text { (Political stability) }\end{array}$ & $\begin{array}{c}1.7986 \\
{[0.1684]}\end{array}$ & & \\
\hline $\begin{array}{c}\text { CRE } \\
\text { (Creative outputs) }\end{array}$ & & $\begin{array}{c}0.12399 \\
{[0.3552]}\end{array}$ & \\
\hline $\begin{array}{c}\text { HUM_CAP } \\
\text { (Human capital and research) }\end{array}$ & & $\begin{array}{l}-0.29163 \\
{[0.0269]} \\
\end{array}$ & \\
\hline $\begin{array}{c}\text { INFR } \\
\text { (Infrastructure) } \\
\end{array}$ & & $\begin{array}{c}0.6755 \\
{[0.0000]}\end{array}$ & \\
\hline GDP_cap & & $\begin{array}{l}0.000185 \\
{[0.0044]}\end{array}$ & $\begin{array}{l}0.000476 \\
{[0.0000]}\end{array}$ \\
\hline $\begin{array}{c}\text { MARK } \\
\text { (Market sophistication) }\end{array}$ & & $\begin{array}{l}0.308786 \\
{[0.0036]}\end{array}$ & \\
\hline $\begin{array}{c}\text { MACRO_stab } \\
\text { (Macroeconomic stability) }\end{array}$ & & $\begin{array}{c}-3.463 \\
{[0.0010]}\end{array}$ & \\
\hline $\begin{array}{c}\text { TECH } \\
\text { (Knowledge and technology outputs) }\end{array}$ & & $\begin{array}{l}0.19076 \\
{[0.0743]}\end{array}$ & \\
\hline $\begin{array}{c}\text { BUSS } \\
\text { (Business sophistication) }\end{array}$ & & $\begin{array}{c}-0.232435 \\
{[0.1754]}\end{array}$ & \\
\hline $\begin{array}{c}\text { R\&D } \\
\text { (Research and Development) }\end{array}$ & & & $\begin{array}{l}0.27272 \\
{[0.0093]}\end{array}$ \\
\hline GINI & & & $\begin{array}{l}-0.25884 \\
{[0.0047]}\end{array}$ \\
\hline $\begin{array}{c}\text { HUM } \\
\text { (Human capital training) }\end{array}$ & & & $\begin{array}{l}-0.3854 \\
{[0.0000]}\end{array}$ \\
\hline $\begin{array}{c}\text { FDI } \\
\text { (Foreign direct investments \%) }\end{array}$ & & & $\begin{array}{l}-0.15211 \\
{[0.0005]}\end{array}$ \\
\hline R square & 0.70 & 0.75 & 0.66 \\
\hline Normality test (Jarque-Bera) & $\begin{array}{c}1.9607 \\
{[0.3752]}\end{array}$ & $\begin{array}{c}2.0301 \\
{[0.3624]}\end{array}$ & $\begin{array}{r}1.03975 \\
{[0.5946]}\end{array}$ \\
\hline Heteroscedasticity test (Harvey) & {$[0.2575]$} & $\begin{array}{c}1.41998 \\
{[0.2025]}\end{array}$ & $\begin{array}{l}1.51203 \\
{[0.1972]}\end{array}$ \\
\hline ARCH effect test & $\begin{array}{c}0.1225 \\
{[0.7263]}\end{array}$ & $\begin{array}{c}0.8931 \\
{[0.3446]} \\
\end{array}$ & $\begin{array}{l}2.00573 \\
{[0.1614]}\end{array}$ \\
\hline Heteroscedasticity test (White) & {$[0.0011]$} & $\begin{array}{c}1.3165 \\
{[0.097]}\end{array}$ & $\begin{array}{c}1.06783 \\
{[0.4042]}\end{array}$ \\
\hline RESET test & $\begin{array}{l}0.24234 \\
{[0.6225]}\end{array}$ & $\begin{array}{c}1.1428 \\
{[0.2568]}\end{array}$ & $\begin{array}{c}0.4279 \\
{[0.6700]}\end{array}$ \\
\hline
\end{tabular}




\section{Discussion}

Research on enabling conditions of CSR implementation necessitates expanded analytical lenses in order to deliver a better understanding of why and/or how corporate responsibility is materialized and shaped among the various levels of analysis (Blowfield, 2005): the micro-, meso- and macro-level. In this context, empirical evidence linking country-level innovative capacity to CSR is still sparse (Gallego-Alvarez et al., 2011; Luo and Du, 2015; Shen et al., 2016) with the academic debate on interrelationships between the two constructs to be mostly fueled by normative assumptions and conceptual arguments. With CSR research being 'innovation-limited' and empirical findings linking national innovation specificities to CSR to be nonexistent, this paper sought to shed light on CSR's heterogeneity among a large number of countries by offering evidence on the degree to which innovation-specific elements influence country-level CSR penetration. With this in mind, the study is both timely and relevant, contributing to a considerably understudied aspect of the business literature given the paucity of prior empirical studies on the topic. Focusing on the macro-level, findings do not contradict prior (but limited) evidence on CSR practices vis-a-vis innovation (see Gallego-Alvarez et al., 2011), yet, the negative associations found in our model specifications (which are empirically supported and internally consistent) warrant further attention and investigation. By drawing on cross-sectional data from de facto international CSR schemes and well-established innovation metrics, the analysis indicates that patent applications and knowledge-technology outputs, institutional efficiency, market sophistication and robust infrastructure networks may explain country-level CSR penetration. Likewise, research and development along with human capital training (as critical elements of innovative capacity) can also positively affect CSR adoption and engagement. Such findings highlight the need for additional research in order to gain a better understanding of 
how the innovative potential among countries may explain the propensity of a country's business system to actively engage in CSR.

\section{Policy implications}

National and transnational policy-design seeking CSR endorsement through innovation proliferation should be aware of, innovation-specific, determinants which may be in a unique position to influence a robust agenda-setting for corporate responsibility. Taking into account that contextual-institutional conditions strongly determine organizational behavior (Hall and Soskice, 2001; Judge et al., 2008), policy-makers could endorse CSR penetration through the configuration on innovation-adapted CSR policies, devised around the creation of reward schemes, incentives, awareness raising initiatives as well as capacity-building programs. Indeed, transnational policy-making should consider innovation as an essential component towards meaningful CSR proliferation and develop appropriate country-specific policy frameworks that account for intrinsic national innovation characteristics. Policy design for CSR dissemination cannot afford to be misinformed of predominant innovation dynamics that drive business development, as they may prove to be driving forces in effective sustainable development strategies and facilitate value-creating CSR. Likewise, by providing innovation-specific market intelligence, filling innovation-related knowledge gaps and/or disseminating best-practices guides may assist in creating an enabling environment for meaningful CSR implementation by firms operating in international markets. 


\section{Managerial implications}

The paper extends innovation studies under the scope of organizational responsibility, providing fruitful insights on CSR embeddedness as well as on contextual factors which may shape better corporate nonmarket strategies. Such innovation-related factors could be addressed when leveraging organizational resources to support CSR-based competencies and leadership. Therefore, such an assessment encapsulates managerial implications as it informs possible avenues for increased integration of CSR within business strategy and planning towards innovative competitive advantages. Implementing training and development programs in order to assist business executives to gain better apprehension of how nurturing innovation, may assist in opting for more effective strategic approaches towards CSR integration within the enterprise. With a growing number of firms launching and developing nonmarket (i.e. CSR) strategies, it is crucial to reconsider corporate responsibility as an avenue of new, potentially disruptive, innovations and competence-building especially for those industries where differentiation is highly important. Likewise, taking into account that sustainable competitive advantages may lie on an array of distinct core business competencies, innovation and corporate responsibility may reflect two essential ones (Barney, 1991; Hamel, 2000).

Studies such as ours may guide practitioners towards a better apprehension of how and where innovation and corporate responsibility may intersect but also to support top management and CSR executives in deciding whether a global CSR strategy can be efficiently implemented or local innovation attributes could be taken into account in adjusting country-specific or regional strategies in order to align the enterprise's CSR vision with the various national contexts they operate in. Operating in a number of innovation-diverging national terrains predicates that it could be beneficial for a firm's CSR agenda to be adapted 
and localized, taking into consideration the innovative potential exhibited by host countries. For instance, for promoting CSR implementation in national environments with increased number of patent applications, sophisticated $R \& D$ and high quality human capital training, business entities could devise appropriate strategies in order to take advantage of such intangible assets and potentially yield nonmarket competencies and tacit knowledge timely and effectively. Likewise, in countries characterized by highly competent scientific research institutes, robust infrastructure systems or increased market sophistication, the CSR agenda could be customized accordingly in order to ensure a more positive impact of related organizational plans and programs. This can be particularly important for business entities with increased levels of internationalization, considering that CSR is often pinpointed as a source of innovations for business entities and subsidiaries have been characterized as hubs of innovative techniques and competence-building within host-country business systems (Birkinshaw et al., 2005; Monteiro et al., 2008).

\section{Concluding remarks}

The paper is not without limitations that highlight fruitful opportunities for further research. As the underlying link between the two multifaceted concepts is complex, the study's findings emphasize that innovation should be included in empirical models investigating moderators of CSR adoption, opting for alternative or industry-specific metrics of CSR penetration and innovative capacity. The NCSRI index employed in operationalizing CSR penetration relies on secondary data derived from internationally-accepted schemes and excludes those regional and/or country-specific initiatives that firms may support. By relying on the NCSRI a large number of countries has been excluded, leaving plenty of room for novel and perhaps more rigorous constructs of macro-level CSR assessment to be devised 
and applied on larger samples or specific regional settings which could test the soundness of our findings. Such measures could draw beyond secondary/archival data, where this study relied on, and focus on primary data. Future research may consider such regional schemes in devising respective country-level CSR variables and also incorporate regionally-specific control variables into model specifications. In this respect, researchers could utilize structural equation modelling and panel data over a timeline to allow a dynamic investigation of how core elements of national innovative potential may influence CSR and its various dimensions (Hull and Covin, 2009).

Moreover, the study followed a macro-level analytical lens, which reflects the least studied level of CSR investigation. Indeed, country-level CSR penetration is inherently dynamic and a multi-level process between companies (i.e. micro-level), industries (mesolevel) and contextual factors (i.e. macro-level). Therefore, for a better apprehension of how innovative CSR is becoming part of organizational routines in country's business sector, research has to investigate the phenomenon from diverse perspectives utilizing appropriate variables at the various levels of analysis and exploring interactions occurring between levels (e.g. from the sectoral level to the individual company). To achieve this, longitudinal studies or action research may offer critical evidence on where the two constructs intersect within the various levels of analysis. Such qualitative approaches could allow documentation on subtle innovation elements that influence CSR activities during the various implementation phases (early adoption, development or maturity stages). Scholars could expand such lines of research and examine how national innovative capacity generates different types of organizational responsiveness between countries in terms of stakeholder management and accountability. Such research perspectives may advance the debate between innovation and CSR and offer critical information to support theory refinement, given that the present study indicates how theoretical development in the particular strand of organization studies would 
benefit from further integrating conceptual insights drawn from these two complex and multidimensional constructs.

\section{Acknowledgements}

Thanks are due to Prof Almeida, Prof Lindahl and the anonymous referees for their valuable comments and recommendations. Any remaining errors on any aspect of the paper are solely the authors' responsibility. 


\section{References}

Amit, R.H., Zott, C., 2010. Business model innovation: Creating value in times of change. IESE Business School Working Paper No. 870. University of Navarra, Barcelona. Available at SSRN: https://ssrn.com/abstract=1701660.

Baldwin, E., Curley, M., 2007. Managing IT innovation for business value, IT best practice series. Intel Press, Santa Clara.

Barney, J.B., 1991. Firm resources and sustained competitive advantage. Journal of Management 17(1): 99-120.

Bendell, J., Visser, W., 2005. World review. The Journal of Corporate Citizenship, 17, 5-20.

Birkinshaw, J., Young, S., Hood, N., 2005. Subsidiary entrepreneurship, internal and external competitive forces, and subsidiary performance. International Business Review, 14(2), 227-248.

Blowfield, M., 2005. Corporate social responsibility - The failing discipline and why it matters to international relations. International Relations, 19(2), 173-191.

Bocquet, R., Mothe, C., 2011. Exploring the relationship between CSR and innovation: A comparison between small and large sized French companies. Revue Sciences de Gestion, Institut de Socio-Economie des Entreprises et des Organisations (ISEOR), 101-119.

Brammer, S., Millington, A., 2008. Does it pay to be different? An analysis of the relationship between corporate social and financial performance. Strategic Management Journal, 29, 1325-1343. 
Chandler, G.N., Keller, C., Lyon, D.W., 2000. Unraveling the determinants and consequences of an innovation supportive organizational culture. Journal of Business Venturing, 8, 391-408.

Chesbrough, H., 2003. Open innovation: the new imperative for creating and profiting from technology. Harvard Business School Publishing, Boston.

Cohen, B., Winn, M.I., 2007. Market imperfections, opportunity and sustainable entrepreneurship. Journal of Business Venturing, 22(1), 29-49.

Crets, S., Celer, J., 2013. The interdependence of CSR and social innovation. In: Social Innovation, Springer: Berlin Heidelberg, 77-87.

Donaldson, T., Dunfee, T., 1999. Ties that bind. A social contracts approach to business ethics. Harvard Business School Press, Boston.

Drucker, P.F., 1985. Innovation and entrepreneurship. Harper Trade, New York.

Dutta, S., 2012. Global Innovation Index 2012: Stronger Innovation Linkages for Global Growth. INSEAD, Paris.

Fox, T., 2004. Corporate social responsibility and development. Development, 47(3), 29-36.

Freeman, R.E., Harrison, J., Wicks, A., Parmar, B., De Colle, S., 2010. Stakeholder theory: the state of the art. Oxford University Press, Oxford.

Gallego-Alvarez, I., Manuel Prado-Lorenzo, J., García-Sánchez, I.M., 2011. Corporate social responsibility and innovation: a resource-based theory. Management Decision, 49(10), 1709-1727.

Gjølberg, M. 2009. Measuring the immeasurable? Constructing an index of CSR practices and performance in 20 countries. Scandinavian Journal of Management, 25, 10-22. 
Googins, B., 2013. Transforming corporate social responsibility: leading with innovation. In: Osburg T, Schmidpeter R (eds) Social innovation - solutions for a sustainable future. Springer, Heidelberg.

Grayson, D., Hodges, A., 2004. Corporate Social Opportunity! 7 Steps to Make Corporate Social Responsibility Work for Your Business. Sheffield: Greenleaf.

Grieshuber, E., 2013. Innovation through corporate social responsibility?. In Social Innovation, Springer: Berlin Heidelberg, 197-206.

Halkos, G., Skouloudis, A., 2016. National CSR and institutional conditions: An exploratory study. Journal of Cleaner Production, 139, 1150-1156.

Halkos, G., Skouloudis, A. 2017. Revisiting the relationship between corporate social responsibility and national culture: A quantitative assessment. Management Decision, 55(3), 595-613.

Hall, P.A., Soskice D., 2001. An introduction to varieties of capitalism. In P.A. Hall and D. Soskice (Eds.), Varieties of capitalism: The institutional foundations of comparative advantage. Oxford, MA: Oxford University Press, 1-68.

Halme, M., Laurila, J., 2008. Philanthropy, integration or innovation? Exploring the financial and societal outcomes of different types of corporate responsibility. Journal of Business Ethics.

Hamel, G.. 2000. Leading the Revolution. Harvard Business School Press: Boston, MA.

Hockerts, K. 2003. Sustainability innovations, ecological and social entrepreneurship and the management of antagonistic assets. University of St. Gallen. 
Hockerts, K., Wüstenhagen, R., 2010. Greening Goliaths versus emerging Davids Theorizing about the role of incumbents and new entrants in sustainable entrepreneurship. Journal of Business Venturing, 25(5), 481-492.

Hull, C.E., Covin, J.G., 2009. Learning capability, technological parity, and innovation mode use. Journal of Product Innovation Management, 26.

Hull, C.E., Rothenberg, S., 2008. Firm performance: the interactions of corporate social performance with innovation and industry differentiation. Strategic Management Journal, 29, 781-789.

Husted, B.W., Allen, D.B., 2007. Strategic corporate social responsibility and value creation among large firms: lessons from the Spanish experience. Long Range Planning, 40, 594-610.

Johnson, M., Suskewicz, J., 2009. How to jump-start the clean tech economy', Harvard Business Review, 87(11), 52-60.

Judge, W.Q., Douglas, T.J., Kutan, A.M. 2008. Institutional antecedents of corporate governance legitimacy. Journal of Management, 34, 765-785.

Kaasa, A., Kaldaru, H., Parts, E., 2007. Social capital and institutional quality as factors of innovation: evidence from Europe. University of Tartu-Faculty of Economics \& Business Administration Working paper series, 55, 1-56.

Luo, X., Du, S., 2015. Exploring the relationship between corporate social responsibility and firm innovation. Marketing Letters, 26(4), 703-714. 
Lockett, A., Moon, J., Wayne, V., 2006. Corporate social responsibility in management research: focus, nature, salience and sources of influence. Journal of Management Studies, 43, 115-136.

Lopez-Claros, A., Mata, Y.N., 2011. Policies and institutions underpinning country innovation: Results from the innovation capacity index. In: The innovation for development report 2010-2011, Palgrave Macmillan UK, 3-63.

Lopez, M.V., Perez, M.C., Rodriguez, L., 2008. Strategy, corporate social responsibility and R\&D expenditure: empirical evidence of European convergence. Paper presented at the 31st Annual Congress of the European Accounting Association, Rotterdam.

MacGregor, S.P., Fontrodona, J., 2008. Exploring the fit between CSR and innovation. IESE Business School Publishing, Barcelona.

Maroušek, J. 2013. Study on agriculture decision-makers behavior on sustainable energy utilization. Journal of Agricultural and Environmental Ethics, 26(3), 679-689.

Maroušek, J., Hašková, S., Zeman, R., Vaníčková, R. 2015. Managerial preferences in relation to financial indicators regarding the mitigation of global change. Science and engineering ethics, 21(1), 203-207.

Maroušek, J., Hašková, S., Zeman, R., Žák, J., Vaníčková, R., Maroušková, A., Váchal, J., Myšková, K. 2016. Polemics on ethical aspects in the compost business. Science and Engineering Ethics, 22(2), 581-590.

McWilliams, A., Siegel, D., 2000. Corporate social responsibility and financial performance: correlation or misspecification?. Strategic Management Journal, 21, 603-609. 
Mitchell, D., Coles, C., 2003. The ultimate competitive advantage of continuing business model innovation', Journal of Business Strategy, 24(5), 15-21.

Monteiro, L.F., Arvidsson, N., Birkinshaw, J., 2008. Knowledge flows within multinational corporations: Explaining subsidiary isolation and its performance implications. Organization Science, 19(1), 90-107.

Moon, J., Crane, A., Matten, D., 2005. Can corporations be citizens? Corporate citizenship as a metaphor for business participation in society. Business Ethics Quarterly, 15(3), $429-453$.

Porter, M.E., Kramer, M., 2006. Strategy and society: the link between competitive advantage and corporate social responsibility. Harvard Business Review, December, 78-92.

Porter, M.E., Kramer, M.R. 2011. Creating shared value. Harvard Business Review, 89(1/2), $62-77$.

Porter, M.E., van der Linde, C., 1995. Toward a new conception of the environmentcompetitiveness relationships. Journal of Economic Perspectives, 9(4), 97-118.

Prahalad, C.K., 2005. The Fortune at the Bottom of the Pyramid: Eradicating Poverty through Profits. Wharton School Publishing, Upper Saddle River, NJ.

Prahalad, C.K., Hammond, A., 2002. Serving the world's poor, profitably. Harvard Business Review, 80(9), 48-57.

Prahalad, C.K., Hart, S., 2002. The fortune at the bottom of the pyramid. Strategy \& Business, 26, 1-15. 
Pujari, D., 2006. Eco-innovation and new product development understanding the influences on market performance. Technovation, 26(1), 76-85.

Rake, M., Grayson, D., 2009. Embedding corporate responsibility and sustainability everybody's business. Corporate Governance, 9(4), 395-399.

Ratajczak, P., Ratajczak, P., Szutowski, D., Szutowski, D., 2016. Exploring the relationship between CSR and innovation. Sustainability Accounting, Management and Policy Journal, 7(2), 295-318.

Roome, N., 2011. A retrospective on globalization and sustainable development: the business challenge of systems organization and systems integration. J Bus Prof Ethics $30(3 \& 4), 193-228$

Schaltegger, S., Wagner, M., 2011. Sustainable entrepreneurship and sustainability innovation: categories and interactions. Business Strategy and the Environment, 20(4), 222-237.

Schumpeter, J.A. (1994/1942) Capitalism, socialism and democracy. Routledge, London.

Shen, R., Tang, Y., Zhang, Y., 2016. Does Firm Innovation Affect Corporate Social Responsibility?. Harvard Business School Working Paper, No. 16-096, February 2016.

Skouloudis, A., Isaac, D., Evaggelinos, K., 2016. Revisiting the national corporate social responsibility index. International Journal of Sustainable Development \& World Ecology, 23(1), 61-70. 
Teece, D.J., 2007. Explicating dynamic capabilities: the nature and microfoundations of (sustainable) enterprise performance. Strategic Management Journal, 28(13), 13191350.

Teece, D.J., 2010. Business models, business strategy and innovation. Long range planning, 43(2), 172-194.

Trebucq, S., Evraert, S., 2008. Adoption of GRI's guidelines reporting by European companies. Paper presented at the 31st Annual Congress of the European Accounting Association, Rotterdam.

World Economic Forum, 2013. The Global Competitiveness Report 2012-2013. World Economic Forum, Geneva.

Yang, Y., Konrad, A.M., 2011. Diversity and organizational innovation: The role of employee involvement. Journal of Organizational Behavior, 32(8), 1062-1083.

Yunus, M., Moingeon, B., Lehmann-Ortega, L., 2010. Building social business models: lessons from the Grameen experience. Long Range Planning, 43(2/3), 308-325.

Zahra, S.A., Covin, J.G., 1995. Contextual influences on the corporate entrepreneurshipperformance relationship: a longitudinal analysis. Journal of Business Venturing, 10, $43-58$.

Zahra, S.A., Neubaum, D.O., 1998. Environmental adversity and the entrepreneurial activities of new ventures. Journal of Developmental Entrepreneurship, 3(2), 123140. 
Appendix 1: National corporate responsibility index - country scores (Skouloudis et al., 2016)

\begin{tabular}{|c|c|c|}
\hline & Country & NCSRI \\
\hline 1 & Switzerland & 20,64 \\
\hline 2 & Sweden & 19,50 \\
\hline 3 & Finland & 18,99 \\
\hline 4 & Denmark & 12,59 \\
\hline 5 & United Kingdom & 9,64 \\
\hline 6 & Netherlands & 9,27 \\
\hline 7 & Norway & 8,04 \\
\hline 8 & Australia & 6,17 \\
\hline 9 & Spain & 4,21 \\
\hline 10 & France & 2,58 \\
\hline 11 & Portugal & 2,30 \\
\hline 12 & Singapore & 0,77 \\
\hline 13 & Japan & $-0,25$ \\
\hline 14 & Canada & $-0,76$ \\
\hline 15 & Belgium & $-1,22$ \\
\hline 16 & Italy & $-1,56$ \\
\hline 17 & Germany & $-3,93$ \\
\hline 18 & Hong Kong & $-5,40$ \\
\hline 19 & Ireland & $-5,70$ \\
\hline 20 & USA & $-11,02$ \\
\hline 21 & Luxembourg & $-11,12$ \\
\hline 22 & Brazil & $-11,74$ \\
\hline 23 & Colombia & $-11,99$ \\
\hline 24 & South Korea & $-12,13$ \\
\hline 25 & Austria & $-12,21$ \\
\hline 26 & South Africa & $-12,58$ \\
\hline 27 & Israel & $-13,57$ \\
\hline 28 & Chile & $-15,13$ \\
\hline 29 & New Zealand & $-15,19$ \\
\hline
\end{tabular}

\begin{tabular}{|llc|}
\hline & Country & NCSRI \\
\hline 30 & Greece & $-15,36$ \\
31 & Thailand & $-17,79$ \\
32 & Romania & $-17,98$ \\
33 & Malaysia & $-18,99$ \\
34 & Hungary & $-19,50$ \\
35 & Bulgaria & $-19,68$ \\
36 & India & $-20,64$ \\
37 & Lithuania & $-20,87$ \\
38 & Slovakia & $-21,73$ \\
39 & Taiwan & $-22,02$ \\
40 & Croatia & $-23,07$ \\
41 & Panama & $-23,41$ \\
42 & Slovenia & $-23,83$ \\
43 & United Arab Emirates & $-24,17$ \\
44 & Serbia & $-24,26$ \\
45 & Sri Lanka & $-24,39$ \\
46 & Latvia & $-24,81$ \\
47 & Indonesia & $-25,03$ \\
48 & Estonia & $-25,12$ \\
49 & Jordan & $-25,19$ \\
50 & Bahrain & $-25,41$ \\
51 & Viet Nam & $-25,55$ \\
52 & Mauritius & $-26,04$ \\
53 & Czech Republic & $-26,25$ \\
54 & Iceland & $-26,36$ \\
55 & Poland & $-26,36$ \\
56 & China & $-26,65$ \\
57 & Peru & $-26,66$ \\
58 & Uruguay & $-26,98$ \\
\hline & & \\
\hline & & \\
36 &
\end{tabular}

\begin{tabular}{|llc|}
\hline & Country & NCSRI \\
\hline 59 & Mexico & $-27,36$ \\
60 & Kazakhstan & $-27,53$ \\
61 & Turkey & $-27,78$ \\
62 & Costa Rica & $-27,84$ \\
63 & Ecuador & $-28,06$ \\
64 & Pakistan & $-28,10$ \\
65 & Argentina & $-28,37$ \\
66 & Bolivia & $-28,37$ \\
67 & Philippines & $-29,56$ \\
68 & Qatar & $-29,65$ \\
69 & Belarus & $-30,18$ \\
70 & Tunisia & $-30,26$ \\
71 & Honduras & $-30,43$ \\
72 & Kuwait & $-30,65$ \\
73 & Kenya & $-30,79$ \\
74 & Egypt & $-31,45$ \\
75 & Ukraine & $-31,66$ \\
76 & Georgia & $-32,26$ \\
77 & Russian Federation & $-32,38$ \\
78 & Oman & $-32,50$ \\
79 & Nigeria & $-33,13$ \\
80 & Guatemala & $-33,51$ \\
81 & Syrian Arab Republic & $-33,70$ \\
82 & Morocco & $-33,94$ \\
83 & Iran & $-34,00$ \\
84 & Bangladesh & $-34,93$ \\
85 & Venezuela & $-35,44$ \\
86 & Saudi Arabia & $-37,06$ \\
& & \\
\hline & & \\
\hline
\end{tabular}

